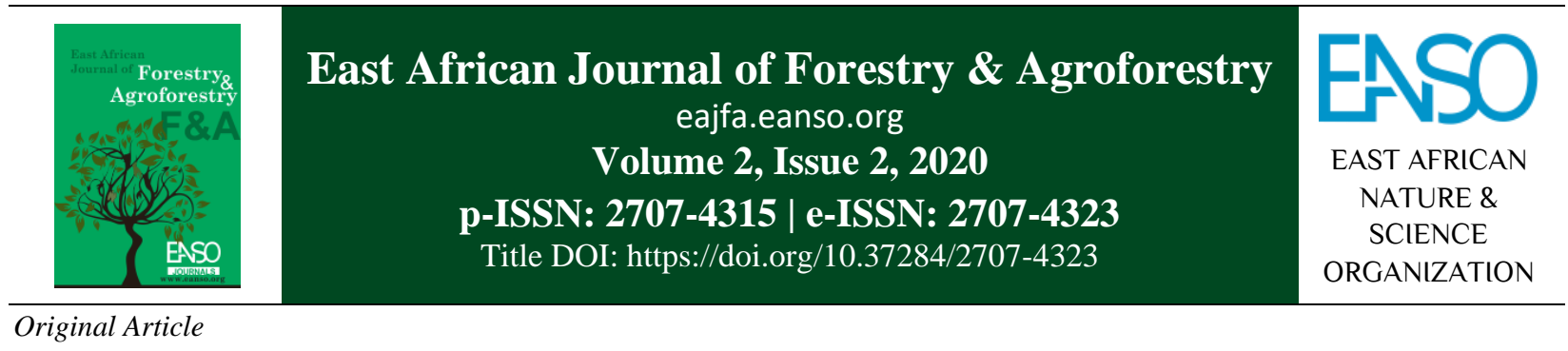

\title{
Investigation of the Effect of Human Disturbances on Mahungu Gree Belt Forest Reserve (MGFR) in Dodoma City, Central Tanzania
}

\author{
Canisius John Kayombo ${ }^{1}$, Chrispinus D. K. Rubanza ${ }^{2}$ \& Richard A. Giliba ${ }^{3}$ \\ ${ }^{1}$ Department of Botany, College of Natural and Applied Sciences, University of Dar es Salaam, Tanzania. \\ ${ }^{2}$ College of Natural and Applied Sciences, the University of Dodoma- Tanzania. \\ ${ }^{3}$ Forestry Training Institute, Olmotonyi. P. O. Box 35091, Dar es Salaam, Tanzania. \\ *Author for Correspondence email: kayombo33@yahoo.co.uk or kayombocanisius@ gmail.com
}

Article DOI: https://doi.org/10.37284/eajfa.2.2.156

\section{Article history: ABSTRACT}

19 May 2020 Human disturbances are the human activities, whether legally or illegally conducted in an ecosystem as they may lead to removal or death of plants. The

Keywords: study was piloted at Mahungu Green Belt Forest Reserve (MGFR) in 2015 to examine the effect of human disturbances. Systematic random sampling was

Human disturbances, green belt, legal and

illegal activities,

Mahungu Forest

Reserve.

applied. A total of 36 plots of $50 \mathrm{~m} \times 50 \mathrm{~m}$ were established in the seven transects at an interval of $400 \mathrm{~m}$. Ongoing human activities were identified and recorded. GPS was applied to locate plots, aligning transects and recording coordinates. The compass was used to direct the transect. $100 \mathrm{~m}$ tape was used to measure the plots. Inferential statistics was applied whereby human activities frequency and relative frequency were calculated. The identified and recorded most frequently occurred human activities were firewood collection, charcoal making, grazing and trespass routes. MGFR is potential in terms of biological diversity; it is recommended that; introduction ecotourism as and environmentally friendly projects; determination of all plant species of MGFR; education campaigns by Dodoma Universities; encourage woodlot development at household level; awareness creation; provision of environmental conservation education; enhance non-woody income-generating projects; discourage settlement expansion into the remaining forest patch; funds should be made available throughout to ensure regular patrols by field security guides, and enhance alternative sources of energy to the local people.

\section{APA CITATION}

Kayombo, C., Rubanza, C., \& Giliba, R. (2020). Effect of Human Disturbances on Mahungu Green Belt Forest Reserve (MGFR) in Dodoma City, Central Tanzania. East African Journal of Forestry and Agroforestry, 2(2), 1-15. https://doi.org/10.37284/eajfa.2.2.154

\section{CHICAGO CITATION}


Kayombo, Canisius, Chrispinus Rubanza, and Richard Giliba. 2020. "Effect of Human Disturbances on Mahungu Green Belt Forest Reserve (MGFR) in Dodoma City, Central Tanzania”. East African Journal of Forestry and Agroforestry 2 (2), 1-15. https://doi.org/10.37284/eajfa.2.2.154.

\section{HARVARD CITATION}

Kayombo, C., Rubanza, C., and Giliba, R. (2020) "Effect of Human Disturbances on Mahungu Green Belt Forest Reserve (MGFR) in Dodoma City, Central Tanzania", East African Journal of Forestry and Agroforestry, 2(2), pp. 1-15. doi: 10.37284/eajfa.2.1.154.

\section{IEEE CITATION}

C. Kayombo, C. Rubanza, and R. Giliba, "Effect of Human Disturbances on Mahungu Green Belt Forest Reserve (MGFR) in Dodoma City, Central Tanzania”, EAJFA, vol. 2, no. 2, pp. 1-15, Mar. 2020.

\section{MLA CITATION}

Kayombo, Canisius, Chrispinus Rubanza, and Richard Giliba. "Effect of Human Disturbances on Mahungu Green Belt Forest Reserve (MGFR) in Dodoma City, Central Tanzania”. East African Journal of Forestry and Agroforestry, Vol. 2, no. 1, Jan. 2020, pp. 1-15, doi:10.37284/eajfa.2.2.154.

\section{INTRODUCTION}

Globally, green belts have been known to be areas of vegetation or a mass plantation of pollutanttolerant trees for mitigating the air pollution by intercepting, filtering and absorbing pollutants in a sustainable manner (UNEP, 2007; Missanjo et al. 2015). The green belt is an area of open land or open space around a city on which building is restricted. The National Forest Policy (URT, 1998) stated that green belt is all land bearing a vegetative association dominated by trees of any size, exploitable or not, and capable of producing wood or other products. Forest reserves are portions of state lands where commercial harvesting of wood products is excluded in order to capture elements of biodiversity that can be missing from sustainably harvested sites. Green belt forest reserves represent potential approach towards the enhanced supply of ecosystem goods and services in many urban and peri-urban areas in the tropics, including Dodoma Municipality. MGFR as a part of the whole green belt of Dodoma municipality. It was established by the United Republic of Tanzania under Capital Development Authority (CDA) in 1973 so as to carter for firewood, recreational, windbreak and climate regulation in the city. The sustainability of many forest reserves and green belt forests is threatened by the ongoing high extent of deforestation due to conversion of forest reserves into farmlands and human settlements, thus calling for protection attention. The disappearance of species has been described as a loss of plants and animals with potential economic value. The loss of genetic diversity is as a threat to global climate and the environment hence severely impacting human and environmental sustainability (Huston, 1996). Human beings are connected to plants and animals around them (Sinclair and Ryan, 2011). Biological diversity often has immediate significance to traditional societies whose people live close to the land and water sources (Primack, 2006).

Forests are very important in Tanzania due to the ecosystem goods and services they offer to people and the ecosystem as a whole. Forests provide firewood, charcoal, wild edible fruits, poles, timber and tubers (Mugasha et al., 2013). The services offered by forests include water catchments, carbon dioxide sink, and shelter. They also, support wildlife, as well as provide, regulation of temperature and rainfall, prevention of landslides, among other services (Kupnick, 2001). Woody plants, including shrubs, woody climbers and trees play an important role such as generating of income to the people through various exploitation (Malimbwi et al., 2010). Kupnick (2001) stated that the diversity of plant life is an essential underpinning of most of the terrestrial ecosystems. In the tropics alone, it has been estimated that 25,000-30,000 species are in use for various purposes (Howell et al., 1961). According to Environmental condition of Tanzania report (URT, 2008), the daily human needs for vegetation resources are always the most threats to the existing plant species diversity, as most of them involve the removal of plant materials. Most of the vegetated areas were very safe when the human population was low; however today they are increasingly getting depleted to the level that we cannot have a 
clear idea of the number of plant species existing in our environment.

The Dodoma Green Belt Forest Reserve was announced in the CDA report (URT, 1976) as an area for recreational purposes, source of dead firewood, windbreak, soil erosion prevention and protection of biological diversity. A number of studies conducted in European countries revealed that elevated overexploitation of forest resources both in the urban and wild started in the 1990s (Parviainen et al., 2000) Urban forests faced a great challenge from the change of land uses such as settlement instead of the former aims of protection for recreational purposes. In the wild, open and protected land destruction was a result of the expansion in technology that demanded forest materials for furniture, construction, and also establishment of new settlement or institutions. Many countries remain not focused thoroughly on plant species diversity and human disturbances to the ecosystem natural resources (Brown et al., 2007) of which Dodoma in Tanzania is among them. Human activities, whether legal such as accesses roads or illegal like logging have a negative impact on the ecosystem.

\section{Influence of Human Population to Plant Species Diversity}

Vegetation condition has been reduced considerably over the years by human activity and together with frequent fires leaving very small sections of the original ecosystems leading to a large-scale change on plant species composition, dominance and diversity (Sinclair \& Ryan, 2011). The human population increase leads to challenges on natural environment including vegetation depletion due to the overwhelming demand for plant resources in public areas, hence more pressure on the protected areas (Margulis and Schwartz, 2000). In addition, Zimmerman et al. (1996) and Manning et al. (2001) pinpointed that the growth of the human population and increasing urbanization has led to the shrinking or total destruction of the habitats of many plants and the changes can only be observed through organized botanical research. The dramatic and continued reduction in the population of plant species for the reasons other than habitat loss, particularly for high-value timber species where over-harvesting threatens wild populations (Smith and Wyk, 2008).

Over the last decades, it has been observed that the wealth of living forms inclusive of plants is being lost. The consequences of this loss cannot be foreseen, but it is generally recognized to be one of the greatest problems the human being is expected to face in the future (Smith and Wyk, 2008). Plant species diversity is shaped by their extraction and use by humans. In the natural and human process, plant diversity has developed with continuous gain and loss, though it is clear that in recent decades the balance has become negative (Margulis and Schwartz, 2000). The environmental change revolves around questions of how we measure real change and how much of the observed change results from various factors such as human activities, wildlife congestion and wildfires (Smith and Wyk, 2008).

According to National Beekeeping Programme (URT, 2004), Tanzania has a good environment for producing various products, among them bee products favored by the high diversity of plant species that provides nectar and pollen that attract honey bees. The threats to a number of plants are manifold ranging from unsound agricultural practices, urban expansion and industrial development to injudicious and non-suitable collecting by enthusiasts, an increasing need for plant material resource and supply of traditional medicine and sometimes simply ignorance about the plight of the environment in general (Smith and Wyk, 2008). The successive patterns of human land use, including pastoralists, agro-pastoralists, agrarian communities and hunter-gatherers have contributed to climate change and thus generating a diverse and dynamic ecology (Maunder et al., 2002).

The main threat to vegetation in East Africa is from the felling of trees for small scale agriculture (Maunder et al., 2002). Beentje (1994) pinpointed that most of our beautiful natural vegetation and plant species are facing a number of challenges including damage caused by human activities that alter their composition and diversity. Native vegetation areas are complemented with exotic plants, especially in settlements, of which some have become invasive. However, little has been 
done on the assessment of plant species diversity as well as their associated composition dynamics (Beentje, 1994).

\section{Factors Influencing Disturbances on Mahungu Green Belt Forest Reserves (MGFR)}

The need for goods and services offered by the ecosystem calls for overexploitation of biological diversity (Malmer and Nyberg, 2008). While the conservation organizations strive for resources protection, communities struggle harvesting such resources to improve their livelihood. The Ujamaa Community Resource Team (2010) highlighted that natural resources are strained when there is a direct benefit to the community through the generation of income and other associated tangible resources. Naughton (2007) conducted an investigation on green belt diversity and revealed that poverty, improved technology and increase in population intensifies the rate of demand for the ecosystem protected natural resources including land for settlement, even though the land-use zoning set aside some areas for protection purposes. Further exploration is vital to found out the challenges facing the species diversity.
The world accommodates enormous plant species diversity with a variety of values to both human beings and wildlife (Sapieha, 2008). Recently, Tanzania's average annual deforestation rate has been revealed to be at a global high of per cent, more than twice the global average of 0.5 per cent. The country is losing between 300,000 to 400,000 hectares of forest each year, and experts warn over the possibility of increasingly rapid climate change effects (Kessy, 2013). Little has been documented on the human disturbances to forest reserves. Mligo (2011) noted that the forest species are threatened because of cultivation, firewood collection, charcoal making and expansion of settlements. Most of the wetlands of south sub-Saharan, including Botswana and Tanzania are polluted, thus affecting aquatic life; however, much has not been studied thoroughly (Goldberg, 2015). The human activities, whether legal or illegal have a potential influence to plant species diversity of which the world of science may not be aware. This study aimed to investigate the effect of human disturbances (activities) on MGFR, as shown in Figure 1 below.

Figure 1: Conceptual Framework

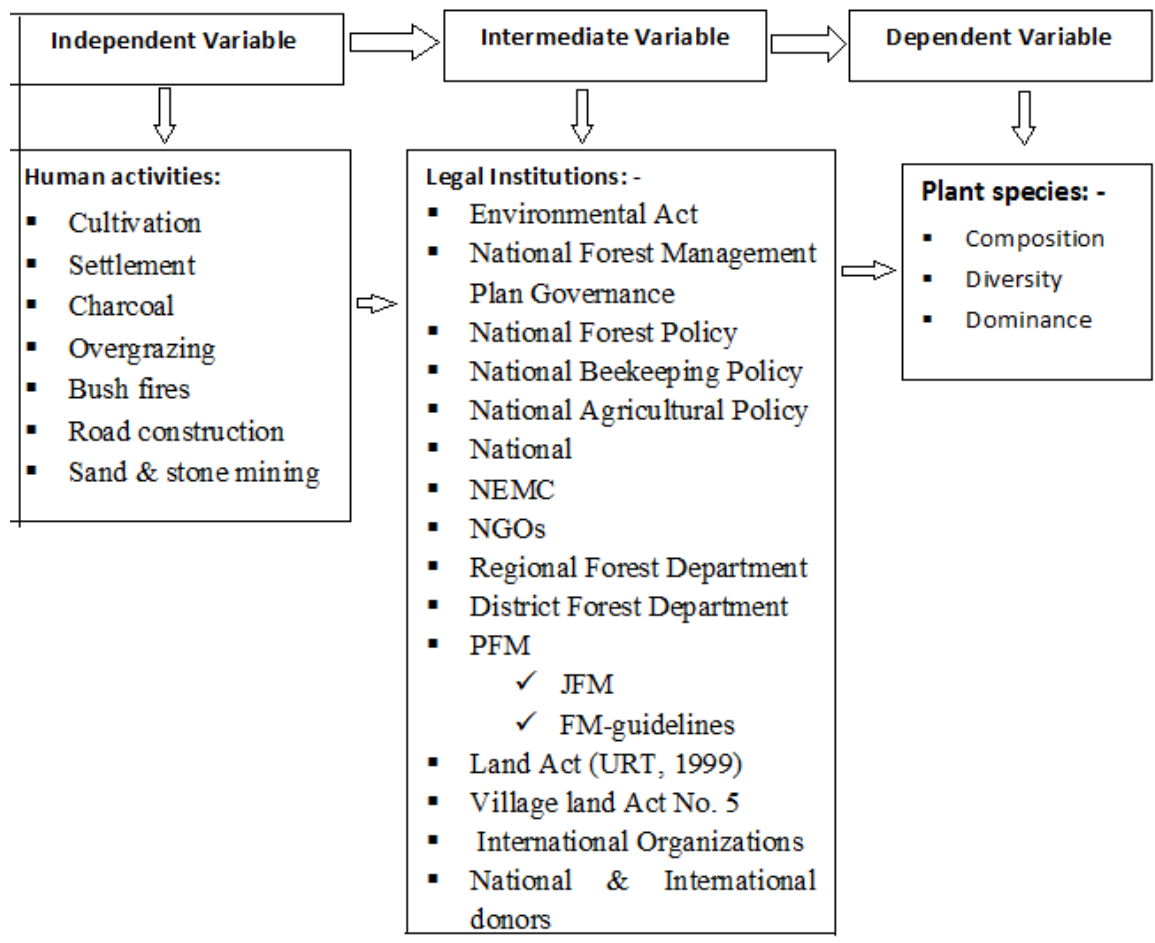




\section{MATERIAL AND METHODS}

\section{Description of Study Area}

The study was conducted at Mahungu Green Belt Forest Reserve (MGBFR) located at $6^{0} 23^{\prime} 5^{\prime \prime} \mathrm{S}$ and $35^{\circ} 45^{\prime} 42^{\prime \prime}$ E continuing to the south at $6^{0} 18^{\prime} 7^{\prime \prime} \mathrm{S}$ and $35^{\circ} 48^{\prime} 9^{\prime \prime} \mathrm{E}$, also, $6^{0} 15^{\prime} 07^{\prime \prime} \mathrm{S}$ and $6^{0} 51^{\prime} 2^{\prime \prime} \mathrm{E}$ to the west and $6^{0} 08^{\prime} 33^{\prime \prime} \mathrm{S}$ and $35^{\circ} 40^{\prime} 08^{\prime \prime}$ E to the eastern end of the forest reserve (Garmin GPS).
According to URT (2014), Mahungu Green Belt Forest Reserve is situated $10 \mathrm{~km}$ west of Dodoma Municipality Centre near tarmac road to Bahi District. Mahungu Green Belt Forest Reserve borders the three villages which are Nala to the northern and western side and Zuzu Village to the southern side of the forest both being in Nala ward. In the eastern side, the forest reserve borders the Mbwanga Village which is in Kizota Ward.

Figure 2: Location of Mahungu Green Belt Forest Reserve (MGFR)

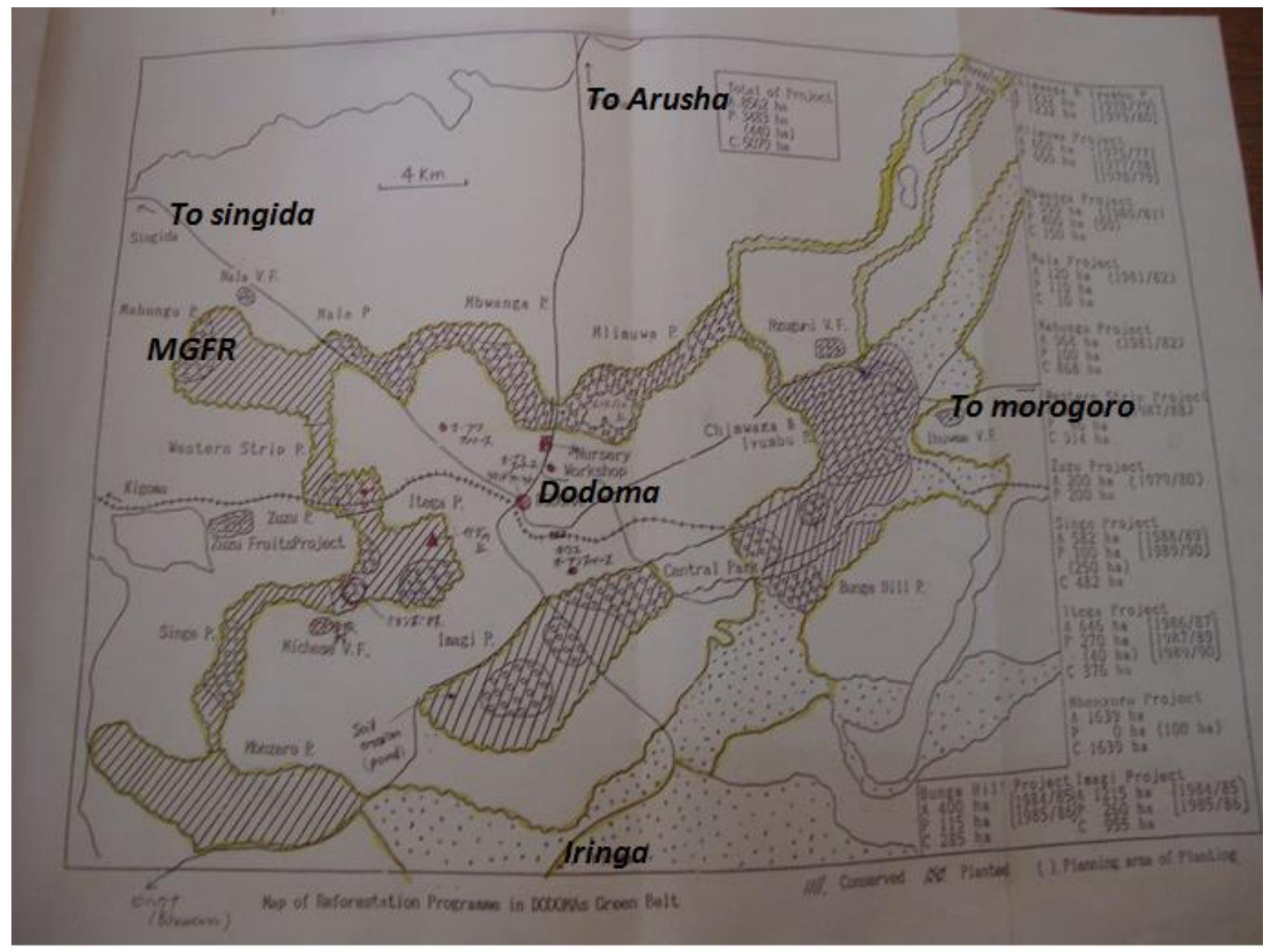

Source: (URT, 1976)

The MGBFR being in the Dodoma region is characterized by broad upland plains which are part of East African's Central Plateau. The Plains shelve gently down to Mbuga swamps and separated by ranges of hills and punctuated by inselbergs, prominent, isolated rock outcrops. In their natural state, the plains are marked by open grassland with little or no tree or bush cover. Due to the erratic nature of the rains and strong radiation heat of the sun, much of the grass is sparse, except in the low- lying areas (URT, 2014). Most common, however, are wooded grassland and bushland with thickets. These types of ground cover represent the majority in Dodoma area. In many areas, they are typified by groups of enormous baobab trees. The bush tends to be leafless and dry in the dry season, but springs to luxuriant life during the rains when the whole countryside turns a brilliant green. Woodlands form the remaining area with the 
heaviest concentrations on the hills of the region Capital Development Authority (URT, 2002).

The vegetation of Mahungu Forest Reserve is dry savanna shrub-thicket land with scattered trees and grassland patches interrupted with trees and shrubs. The common plant species include Commiphora coerulea, C. ugogensis, C. africana, Acacia tortilis, A. senegal, Maerua decumbens, Combretum apiculatum, Grewia forbesii, Brachystegia spiciformis, Sclerocarrya birrea, Julbernardia globiflora, Delonix elata, Markhamia acuminata as indigenous taxa, while the exotics include Peltophorum pterocarpum. MGFR, being in Dodoma region has a dry savanna type of climate characterized by a long dry season lasting between late April to early December and a short single wet season during the remaining months. The region lies in a rain shadow behind the mountains area of Dodoma on the eastern side (URT, 2002). The temperature of the region varies according to altitude, but generally the average maximum and minimum for October to December are $31{ }^{\circ} \mathrm{C}$ and $18{ }^{\circ} \mathrm{C}$ (degrees Centigrade) respectively. The corresponding figures for the cool and dry season of June - August are $27^{\circ} \mathrm{C}$ to $28^{\circ} \mathrm{C}$ and $10^{\circ} \mathrm{C}$ to 11 ${ }^{\circ} \mathrm{C}$ (degree centigrade) (URT, 2002). The average rainfall for Dodoma town is $570 \mathrm{~mm}$, about $85 \%$ of this rainfall is four months between December and March. Rainfall is somewhat higher in the more agriculturally productive parts of Mpwapwa and Kondoa districts. Rainfall in Dodoma region is not only low, but it is rather unpredictable in frequency and amount, particularly in the month of January in which most crops are generally sown (URT, 2002).

The identified agriculture crops grown in Dodoma Municipality were Sorghum bicolour (sorghum), Zea mays (maize), Oryza sativa (paddy), Phaseolus vulgaris (beans), Pennisetum glaucum (bulrush millet), Manihot esculenta (cassava), Arachis hypogaea (groundnuts), Vigna subterranean (Bambara nuts) (URT, 2002). Other crops were Helianthus annuus (sunflower), Sesamum indicum (simsim), Vitis vinifera and $V$. laburnifolia. Dodoma Region is almost entirely dependent on agriculture and animal husbandry, which are practised in rural areas at the subsistence level. It is also one of the regions with large numbers of livestock including cattle, goats, sheep, poultry and pigs (URT, 2002).

\section{Sampling Procedures}

Systematic random sampling was employed during data collection to give equal chances to any element to be selected. The first plot was set randomly at a distance between $50 \mathrm{~m}$ to $100 \mathrm{~m}$ from the reserve edge to avoid the edge effects, then preceded systematically at an interval of $400 \mathrm{~m}$. Systematic random is a probabilistic sampling which is applied to avoid the edge effect. The observed human activities were recorded. The sampling frame was 600 hectares $(6,000,000$ square meters $)$. The sampling unit was a rectangular plot of $50 \mathrm{~m} \times 50$ $\mathrm{m}\left[2,500 \mathrm{~m}^{2}\right]$. Sarma (2006), stated that the basic unit from which the researcher wishes to extract data should be determined. The sample size was 36 plots laid at an interval of $400 \mathrm{~m}$ within which human activities were recorded. The parameters of interest were the human activities in the sample plots. Human activities as parameters of interest are the variables to be investigated (Sarma, 2006).

\section{Data Collection and Analysis}

Observation method was employed whereby the human activities found in the set plots were recorded. Kawulich (2005) argued that observation is a way of gathering data by watching behaviour, events, or noting physical characteristics in their natural setting. Observations were both direct and indirect. Direct observation is when the researcher watches interactions, processes, signs or behaviours as they occur. Indirect observations are when the researcher watches the results of interactions, processes, or behaviours; such as measuring the events such as disturbances done by a person in a particular study site (Kothari, 2004). Data collection checklist was used to record any revealed plant species, as well as the observed human activities. Global Positioning System (GPS) was applied for recording the coordinates of the plot and boundaries of MGBFR, while a compass was used for orientation of the bearing.

Data were analyzed as HA\% $=\frac{\sum \mathrm{n}}{\sum \mathrm{N}} \mathrm{X} 100 \%$; where $\mathrm{HA}=$ a single type of human activity; $\Sigma=$ summation; $\mathrm{n}=$ total occurrence of a single type of human activities; $\mathrm{N}=$ total number of occurrences of all human activities categories. 


\section{RESULTS AND DISCUSSION}

\section{Human Disturbances (activities)}

During this study, a number of human activities were recorded (Table 1). Various reading such as UNDP (2000) has stated that human activities ruin the environmental resources in many of the African countries. Besides, desertification has irreversibly destroyed a great amount of land previously available for grazing. Deforestation for agriculture, charcoal making and soil erosion are equally proceeding at an alarming rate. Furthermore, food production by local people is declining while fuel wood is increasingly hard to collect in most depleted general lands forcing communities to encroach into protected areas (UNDP, 2000). It has been posited that recognition of the causes and effect of environmental variables can help in drawing the conclusions that can help conserve and protect the environment (NGS, 2001). The majority of Tanzanians use fuelwood and charcoal as the main source of energy however the use of charcoal is more pronounced in big cities like Dar-es-salaam $(>83 \%)$ while over $87 \%$ of fuel wood is used in the rural area (the United Republic of Tanzania, 2008). Tanzania depends on charcoal and firewood as sources of energy and thus contributing to environmental damage. Loss of biodiversity and deforestation are among six major environmental problems facing Tanzania, whereas the others include land degradation, accessibility of water, air and water pollution and aquatic systems degradation, which are massively contributed by human activities such as lodging for timber, charcoal production, grazing, and firewood collection (Assey et al., 2007).

In this study, several human disturbances (activities) were identified (Table 1). Legal human activities such as access road or patrol road construction and maintenance, and illegal activities like logging for charcoal, and stone collection were identified at MGFR. Legal activities include settlement, cultivation, tree cutting, road construction, stone collection, timber extraction; grazing, firewood production to list a few, while illegal activities may be as the same as the legal ones, except that they are conducted in the site where it is not permitted, based on the environmental act, laws and policies. Leinster and
Gobbold (2010) pinpointed that the environment we live experiences two major categories of human activities, namely the legal and illegal activities, and all these have an impact to biological species richness and distribution evenness. The protected areas, apart from being under total protection or allowing a very minimal rate of resources collection such as dead woods, still many illegal activities prevail. However, both legal and illegal activities do not guarantee the survival of biological species and the abiotic environment. All categories of human activities may alter the vegetation types of species composition through either removal of the introduction of invasive plant taxa. A study conducted in South America, North America, European, Asian and African continents by Sandbrook et al. (2018) applying camera traps (Bycatch method) revealed illegal human activities in the protected forests seeking for various forest resources. 
Table 1: Human disturbances per plot for plot 1-36

\begin{tabular}{|c|c|c|c|c|c|c|c|c|c|c|c|c|c|}
\hline PLOT NO. & FW & CHC & GR/BR & $\mathbf{C U}$ & UPR & $\mathbf{R P}$ & TPR & SC & SSCR & BK & TAA & TNS & REMARKS \\
\hline 1 & 0 & 0 & 1 & 0 & 0 & 0 & 1 & 0 & 0 & 0 & 2 & 26 & Trample, new dung \\
\hline 2 & 0 & 0 & 1 & 0 & 0 & 0 & 1 & 0 & 0 & 0 & 2 & 30 & Trample, new dung \\
\hline 3 & 0 & 0 & & 0 & 0 & 0 & 0 & 0 & 0 & 0 & 0 & 22 & Intact \\
\hline 4 & 0 & 1 & 1 & 1 & 0 & 1 & 1 & 0 & 0 & 0 & 5 & 18 & $\begin{array}{l}\text { New cow and goat dung } \\
\text { Firewood pieces found, old charcoal }\end{array}$ \\
\hline 5 & 1 & 1 & 0 & 0 & 0 & 0 & 0 & 0 & 0 & 0 & 2 & 30 & kiln \\
\hline 6 & 1 & 0 & 0 & 1 & 0 & 0 & 1 & 0 & 0 & 1 & 4 & 32 & Firewood bundles found \\
\hline 7 & 1 & 0 & 0 & 0 & 0 & 0 & 0 & 0 & 0 & 0 & 1 & 29 & Firewood bundle found \\
\hline 8 & 1 & 1 & 0 & 0 & 0 & 0 & 0 & 0 & 0 & 0 & 2 & 29 & Combretum molle \\
\hline 9 & 0 & 1 & 0 & 0 & 0 & 0 & 0 & 0 & 0 & 0 & 1 & 19 & T. sericea logged \\
\hline 10 & 1 & 1 & 0 & 0 & 0 & 0 & 0 & 0 & 0 & 0 & 2 & 26 & T. sericea logged \\
\hline 11 & 1 & 0 & 0 & 0 & 0 & 0 & 1 & 0 & 0 & 0 & 2 & 25 & J. globiflora logged \\
\hline 12 & 0 & 0 & 0 & 0 & 0 & 0 & 0 & 0 & 1 & 0 & 1 & 24 & Service route \\
\hline 13 & 1 & 1 & 0 & 1 & 0 & 0 & 0 & 0 & 0 & 0 & 3 & 17 & Rods, old kiln \\
\hline 14 & 1 & 0 & 0 & 0 & 0 & 0 & 0 & 0 & 1 & 0 & 2 & 22 & J. globiflora \\
\hline 15 & 1 & 1 & 0 & 1 & 0 & 0 & 0 & 0 & 0 & 0 & 3 & 44 & J. globiflora \\
\hline 16 & 1 & 0 & 0 & 1 & 0 & 0 & 1 & 0 & 0 & 0 & 3 & 15 & J. globiflora \\
\hline 17 & 1 & 1 & 0 & 0 & 0 & 0 & 0 & 0 & 0 & 0 & 2 & 36 & T. sericea \\
\hline 18 & 1 & 1 & 1 & 0 & 0 & 0 & 0 & 0 & 0 & 0 & 3 & 23 & $\begin{array}{l}\text { Old charcoal kiln, cows found } \\
\text { Terminalia sericea \& Delonix elata }\end{array}$ \\
\hline 19 & 1 & 0 & 0 & 1 & 1 & 0 & 0 & 0 & 0 & 0 & 2 & 25 & logged \\
\hline 20 & 0 & 1 & 1 & 0 & 0 & 0 & 0 & 0 & 0 & 0 & 2 & 20 & Old kiln \\
\hline 21 & 0 & 0 & 1 & 0 & 0 & 0 & 1 & 0 & 0 & 0 & 2 & 30 & Goats found \\
\hline 22 & 1 & 1 & 1 & 0 & 0 & 0 & 1 & 0 & 0 & 0 & 4 & 28 & Severely grazed \\
\hline 23 & 0 & 1 & 1 & 1 & 0 & 0 & 1 & 0 & 0 & 0 & 4 & 28 & $\begin{array}{l}\text { 3-old kilns } \\
\text { B. spiciformis, cows, goats \& sheep }\end{array}$ \\
\hline 24 & 1 & 1 & 1 & 0 & 0 & 0 & 0 & 0 & 0 & 0 & 3 & 31 & found \\
\hline 25 & 1 & 1 & 1 & 0 & 0 & 0 & 0 & 0 & 0 & 0 & 3 & 13 & Cows, goats \& sheep \\
\hline 26 & 1 & 1 & 1 & 0 & 0 & 0 & 0 & 0 & 0 & 0 & 3 & 20 & Cows, goats \& sheep \\
\hline
\end{tabular}




\begin{tabular}{llllllllllllll}
\hline PLOT NO. & FW & CHC & GR/BR & CU & UPR & RP & TPR & SC & SSCR & BK & TAA & TNS & REMARKS \\
\hline $\mathbf{2 7}$ & 1 & 0 & 1 & 0 & 0 & 0 & 0 & 0 & 0 & 0 & 2 & 0 & $\begin{array}{l}\text { Old } \\
\text { stuhlmmannii \& Combretum molle cut. } \\
\text { Left firewood, trample } \\
\text { 28 }\end{array}$ \\
& 1 & 0 & 1 & 0 & 0 & 0 & 1 & 0 & 0 & 0 & 3 & 17 & Up routed plants, new dung of goats \\
$\mathbf{2 9}$ & 1 & 0 & 1 & 0 & 1 & 0 & 1 & 0 & 0 & 0 & 3 & 25 & and cows \\
$\mathbf{3 0}$ & 1 & 1 & 1 & 0 & 0 & 0 & 0 & 0 & 0 & 0 & 3 & 22 & 10 -Stumps of $J$ globiflora \\
$\mathbf{3 1}$ & 1 & 1 & 1 & 0 & 0 & 0 & 0 & 0 & 0 & 0 & 3 & 18 & Cow dung, charcoal kiln \\
$\mathbf{3 2}$ & 1 & 1 & & 1 & 0 & 0 & 0 & 0 & 0 & 0 & 3 & 20 & Old charcoal kiln \\
$\mathbf{3 3}$ & 1 & 1 & 1 & 0 & 0 & 0 & 0 & 1 & 0 & 0 & 4 & 27 & Old settlement \\
$\mathbf{3 4}$ & 0 & 0 & 0 & 0 & 0 & 0 & 0 & 0 & 0 & 0 & 0 & 16 & Intact \\
$\mathbf{3 5}$ & 0 & 0 & 0 & 0 & 0 & 0 & 0 & 0 & 0 & 0 & 0 & 13 & Intact \\
$\mathbf{3 6}$ & 0 & 0 & 0 & 0 & 0 & 0 & 0 & 0 & 0 & 0 & 0 & 21 & Intact \\
TOTAL & $\mathbf{2 4}$ & $\mathbf{1 9}$ & $\mathbf{1 7}$ & $\mathbf{8}$ & $\mathbf{1}$ & $\mathbf{1}$ & $\mathbf{1 1}$ & $\mathbf{1}$ & $\mathbf{2}$ & $\mathbf{1}$ & & & \\
\hline
\end{tabular}

\section{Key: -}

FW = Firewood; $\mathrm{CH}=$ Charcoal; GR/BR = Grazing/Browsing; $\mathbf{C U}=$ Cut/Cutting; UPR = Uprooted; RP = Rope; TPR = Trespass Route(s);

SC = Stone collection; SSCR $=$ Security Service Car Route; TAA=Total Human activities; TNS = Total number of species; BK = Beekeeping; $0=$ Not recorded in the plot; $1=$ Recorded in the plot. 
Out of the 10 identified human activities in MGBFR, firewood collection took the lead (67\%), preceded by charcoal (53\%), grazing (47\%), cutting rods size $(22 \%)$, trespass routes $(31 \%)$, service road $(6 \%)$ and the rest activities got $3 \%$. The sum of the percentages sums up more than $100 \%$ because the occurrence of activities has been calculated

Table 2: Human activities occurrence percentage in 36 plots

\begin{tabular}{lll}
\hline Human activity & Total plots activity occurred & Percentage in plots \\
\hline Firewood & 24 & 67 \\
Charcoal & 19 & 53 \\
Grazing & 17 & 47 \\
Cutting & 8 & 3 \\
Uprooting & 1 & 3 \\
Ropes & 1 & 3 \\
Trespass routes & 11 & 31 \\
Stone collection & 1 & 3 \\
Service car routes & 2 & 6 \\
Beekeeping & 1 & 3 \\
\hline
\end{tabular}

The relative frequency revealed $27.0 \%$ for firewood, 21.0 for charcoal, $19.1 \%$ for grazing, $12.4 \%$ for trespass routes, $9.0 \%$ for cutting rod

size, 6.7 for service car routes, and the rest including ropes, uprooting, stone collection and beekeeping got $1.1 \%$ each.

Table 3: Activity, occurrence and relative occurrence in the 36 plots

\begin{tabular}{lll}
\hline Activity & Occurrence & Relative occurrence [\%] \\
\hline Firewood & 24 & 27.0 \\
Charcoal & 19 & 21.0 \\
Grazing & 17 & 19.1 \\
Cutting & 8 & 9.0 \\
Uprooting & 1 & 1.1 \\
Ropes & 1 & 1.1 \\
Trespass & 11 & 12.4 \\
Stone collection & 1 & 1.1 \\
Service car routes & 6 & 6.7 \\
Beekeeping & 1 & 1.1 \\
Total & $\mathbf{8 9}$ & $\mathbf{1 0 0}$ \\
\hline
\end{tabular}

Firewood collection, apart from being legal has implications for planting biological diversity. The collection of dead Woodsy discourages important bacteria and tiny insects carried together with firewood outside the reserve. The soil improvement from the decaying of woody materials is severely discouraged. Also, plant seedlings and lower growing plants are easily destroyed during 
firewood collection. The most damaged woody plant species by human activities were Julbernardia globiflora, Terminalia sericea, Brachystegia spiciformis, Combretum molle, while Lannea schimperi, as well as Brachystegia spiciformis, were debarked for ropes.

\section{Effect of Human Disturbances (Activities)}

Human activities conducted in protected land may lead to removal or damage to resources (Plate 1-5). Most of the human activities involve the removal or damage of plant species in various ways, as highlighted in this study. The findings by Mligo (2011) and Kimaro and Lulandala (2013) revealed that human disturbances had an influence on plant species composition and diversity. Sale \& Francis (2011) who conducted a study on impacts on forests came up with results that human activities led to deforestation, industrialization, and expansion of many other socio-economic activities that collectively led to degradation of environmental resources.

This includes the removal of organic plant materials that were meant to remain improving the soil nutrients for ecological benefits. It also encourages the damage of live trees due to demand for ropes, such as Brachystegia spiciformis and Lannea schimperi bear a suitable bark for ropes (Plate 1). Sassen et al. (2015) study in Uganda found that human activities in protected forests involved wood fuel extraction, illegal commercial fuelwood harvesting. A situation that quantities of dead wood were affected by fuelwood collection up to at least $1000 \mathrm{~m}$ inside the boundary of the park. This implies that the illegal collection of dead woods from protected forests may encourage illegal cutting for commercial purposes and thus leading to damage of biological diversity and or environmental damage in general.

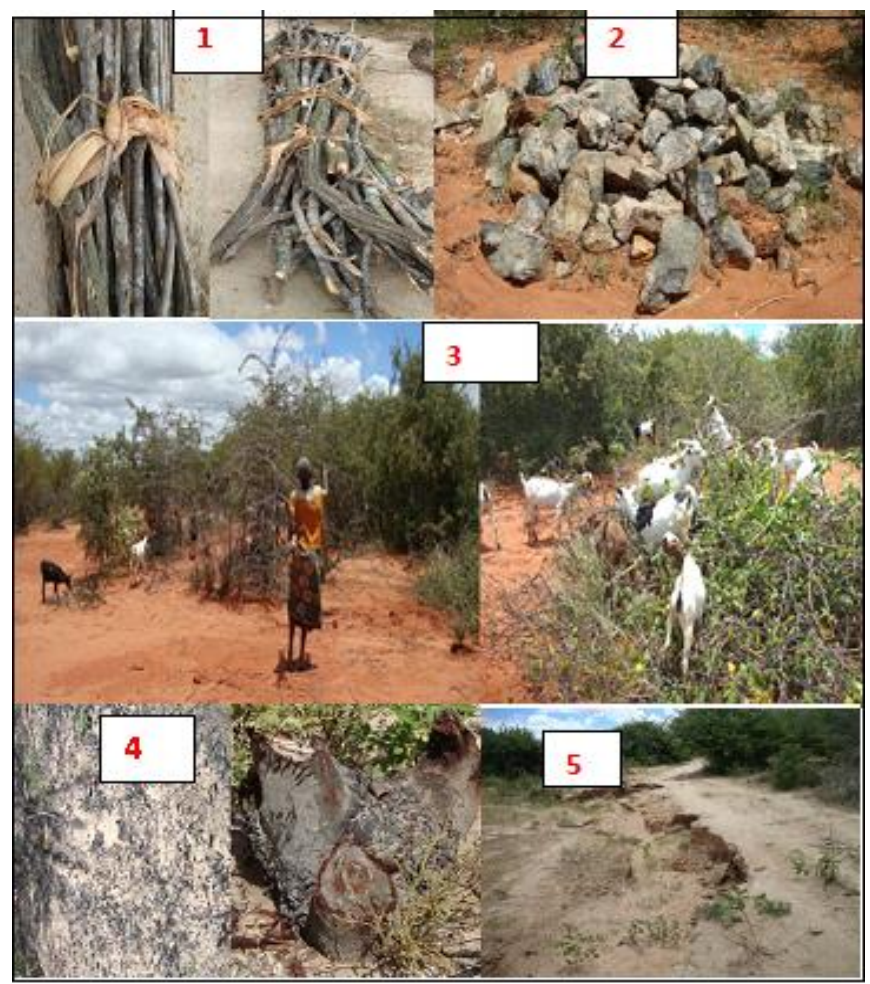

(Plate 1: Firewood tied with barks of Lannea schimperi; Plate 2. Illegal collection of stones in Mahungu Green Belt Forest Reserve (MGFR); Plate 3: Goats browsing in the southern part of Mahungu Forest Reserve; Plate 4: Old kiln near Brachystegia spiciformis stump; Plate 5: Eroded service road in the southwest of Mahungu Green Belt Forest Reserve (MGBFR). 
Goats are the famous browsers, usually damaging leaves and twigs of shrubs, saplings, small trees as well as the lianas. Most of the Legumes and Convolvulaceae family including Turbina stenosiphon. Old women and young boys are regularly found herding livestock in the forest reserve, especially very early in the morning and late in the evening (Plate 3 ). The study conducted in Ethiopia by Giday et al. (2018) revealed that livestock direct browsing and grazing or indirectly by cutting livestock fodder plants, especially during the dry season leading to reduction of plant species inside the forest, an indication that the higher the livestock number in the area the more of the plants were depleted.

Stones are preferred for household's construction as well as a source of income, sold in tones. The accumulation of these stones (Plate 2) is associated with destroying the lower growing plants, seedlings, poles and even larger plants. It also loosens the soil and thus stimulating soil erosion. Charcoal making was noted to be the most damaging activity that involved cutting trees with the highest diameter for higher production of charcoal for sale. The trees ready to produce fruits were revealed to be cut. The situation results in suitable habitat for wildlife was removed, reduced plant diversity and abundance, reduced carbon dioxide sinks and climate regulators reduced the windbreakers and also, spoiled the natural scenery (Plate 4).

Other studies like by Sassen et al. (2015) have supported that charcoal making involves cutting trees, hence leading to damage of forest biodiversity. There were roads that facilitate the passage through the forest reserve regularly by the forest staff. The access routes, apart from being among legal activities, they always involve removing the vegetation, disturbing soil, a process that encourages soil erosion by either wind or water runoff (Plate 5). The study findings by Calskasn (2013) The percent of damage in terms of wounding, bending and crushing of trees were $64 \%$, $31 \%$ and $5 \%$ respectively (for Bulldozer $-\mathrm{I}$ ), 66\%, $24 \%$ and $10 \%$ respectively (for Bulldozer -II), $60 \%$, $34 \%$ and $6 \%$ respectively (for Excavator-I) and $56 \%, 29 \%$ and $15 \%$ respectively (for Excavator II). It was also determined that on steep terrain when excavators were used, $12.23 \%$ less forest area was destroyed compared with when bulldozers were used and $16.13 \%$ less area was destroyed by excavators on very steep terrain.

\section{CONCLUSION AND RECOMMENDATIONS}

There is a linear relationship between the increase in the independent variable (human activities) and the dependent variable (plant diversity, composition and dominance). The legal and illegal human activities had an impact on plant diversity, whereas the illegal ones dominated due to continuous occurrence haphazardly such as charcoal making and overgrazing. The controlled human activities focused only on the well-planned sites, and not otherwise. Protected land faces high pressure from the bordering community as a result of the high demand for natural resources to sustain their life.

From the presently conducted research, recommendations are made in order to sustain the unique forest reserve and ensure sustainable development and environmental management in Dodoma Municipality. Introduction ecotourism as among environmentally friendly project that leads to income generation with minimal damage to abiotic and biotic components; it involves viewing attractive features or natural scenery such as attractive vegetation, big holes, caves, extra-large trees and fauna. Others include determination of all plant species of MGFR, education campaigns by Dodoma Universities, encourage woodlot development at the household level, awareness creation, provision of environmental conservation education, enhance non-woody income-generating projects, discourage settlement expansion into the remaining forest patch, funds should be made available throughout to ensure regular patrols by field security guides, and enhance alternative sources of energy to the local people.

\section{REFERENCES}

Assey, P., Bass, S., Cheche, B., Howlett, D., Jambiya, G., Kikula, I., Likwelile, S., Mayama, A., Magurusi, E., Muheto, R. \& Rutasitara, L. (2007). Environment at the Heart of Tanzania's Development: Lessons from Tanzania's National Strategy for Growth and Reduction of Poverty, MKUKUTA (No. 6). IIED. 
Beentje, H. J. (1994). Kenya trees, shrubs and lianas. Nairobi, KE: National Museum of Kenya.

Brown, T. C., Bergstrom, J. C., \& Loomis, J. B. (2007). Defining, valuing, and providing ecosystem goods and services. Natural Resources Journal, 329-376.

Caliskan, E. (2013). Environmental impacts of forest road construction on mountainous terrain. Iranian journal of environmental health science \& engineering, 10(1), 23. https://doi.org/10.1186/1735-2746-10

Giday, K., Humnessa, B., Muys, B., Taheri, F., \& Azadi, H. (2018). Effects of livestock grazing on key vegetation attributes of a remnant forest reserve: The case of Desa'a Forest in northern Ethiopia. Global ecology and conservation, 14, e00395.

Goldberg, K. (2015). Flooded grassland savanna. Africa: Angola, Botswana, Democratic Republic of Congo, Malawi, Mozambique, Tanzania, Zambia. World Wide Fund

Howell, K. M., Msuya, C. A., Mligo, C., Werema, C., Kihaule, P., Honorati, M. K., \& Suleiman, H. O. (2012). Biodiversity Surveys of Poorly Known Coastal Forests of Southeastern Tanzania and Zanzibar. A consultancy report of the Dept. of Zoology \& Wildlife Conservation to WWF Tanzania

Huston, M. A. (1996). Biological diversity. The coexistence of species on changing Landscapes. Cambridge University.

Kawulich, B. B. (2005). Participant Observation as a Data Collection Method. Journal of Qualitative Social research. 6 (2): 43-44.

Kessy, N. (2013). Tanzania has world's highest rate of deforestation. National Environmental Management Council, Tanzania.

Kimaro, J., \& Lulandala, L. (2013). Human influences on tree diversity and composition of a coastal forest ecosystem: The case of Ngumburuni forest reserve, Rufiji, Tanzania. International Journal of Forestry Research, 2013.
Kothari, C. R. (2004). Research methodology. Methods and techniques. New Age International (P) Ltd. Publishers.

Kupnick, G. (2001). Role of plant diversity. Centre for diversity of America. National Museum of Natural History.

Leinster, T. and Cobbold, C.A. (2010). Measuring diversity: the importance of species Similarity 1School of Mathematics and Statistics. University of Glasgow, UK: Boyd Orr Centre for Population and Ecosystem Health, University of Glasgow.

Malimbwi, R.E., Zahabu, E., Katani, J., Mugasha, W. and Mwembe, U. (2010). Woodlots Management guidelines for smallholder farmers. Faculty of Forestry and Nature Conservation, Sokoine University of Agriculture.

Malmer, A and Gert Nyberg, G. (2008). Forest and water relations in miombo woodlands: Need for understanding of complex stand management. Working Papers of the Finnish Forest Research Institute, 98, 70-86.

Manning, J., Batten, A., \& Bokelmann, H. (2001). Eastern Cape South African wild flower guide 11. Cape Town, South Africa. Botanical Society of South Africa in Association \& National Botanical Institute-Republic of South Africa.

Margulis, L. \& Schwartz, K. (2000). Five kingdoms. An illustrated guide to the phyla of life on earth. Third Edition. New York, NY: W. H. Freeman \& Company.

Maunder, M., Clubbe, C., Hankamer, C. \& Glove, M. (2002). Plant conservation in the Tropics. Perspectives and practice. The Royal Botanic Gardens, Kew.

Missanjo, E., Ndalama, E., Sikelo, D., \& KamangaThole, G. (2015). Quarry dust emission effects on tree species diversity in Chongoni forest reserve and vegetation characteristics in adjacent villages, Dedza, Malawi. International Journal of Information and Review, 2(3), 511-515. 
Mligo, C. (2011). Anthropogenic disturbance on the vegetation in Makurunge woodland, Bagamoyo district, Tanzania. Tanzania Journal of Science, 37(1).

Mugasha, W. A., Eid, T., Bollandsås, O. M., Malimbwi, R. E., Chamshama, S. A. O., Zahabu, E., \& Katani, J. Z. (2013). Allometric models for prediction of above-and belowground biomass of trees in the miombo woodlands of Tanzania. Forest Ecology and Management, 310, 87-101.

National Geographic Society (NGS). (2001). Science voyages. Life science. A Gloncoe Program. MacGraw-Hill Companies.

Naughton Treves, L. (2007). Collaborative land use planning: zoning for conservation and development in protected areas. Land Tenure Center, Nelson Institute of Environmental Studies, University of Wisconsin.

Parviainen, J., Bücking, W., Vandekerkhove, K., Schuck, A., \& Päivinen, R. (2000). Strict forest reserves in Europe: efforts to enhance biodiversity and research on forests left for free development in Europe (EU-COST-Action E4). Forestry, 73(2), 107-118.

Primack, R. B. (2006). Essentials of conservation biology, Third Edition. Sunderland, Massachusetts: Sinauer Associates.

Sale, F. A. \& Francis, A. (2011). Impact of human activities on forest and their effects on climate change. Australian Journal of Basic and Applied Science, 5, 863-867.

Sandbrook, C., Luque-Lora, R., \& Adams, W. M. (2018). Human bycatch: conservation surveillance and the social implications of camera traps. Conservation and Society, 16(4), 493-504.

Sapieha, T. (2008). Wayside Flowers of East Africa. Nairobi, KE: Litho Printers.

Sarma, K. V. S. (2006). Statistics made simple. Do it yourself on PC. Department of Statistics. New Delhi: Sri lank Venkateswara University.
Sassen, M., Sheil, D., \& Giller, K. E. (2015). Fuelwood collection and its impacts on a protected tropical mountain forest in Uganda. Forest Ecology and Management, 354, 56-67.

Sinclair, I. \& Ryan, P. (2011). Birds of Africa. South of the Sahara (2 ${ }^{\text {nd }}$ Edition). Cape Town, SA: Penguin Random House.

Smith, P. G. \& Wyk, B. V. (2008). The United Kingdom garden succulent's primer. How to identify and grow the most popular droughttolerant plants.

Ujamaa Community Resource Team. (2010). Participatory Land Use Planning as a Tool for Community Empowerment in Northern Tanzania. London, UK: International Institute for Environmental Development.

United Nations Environmental Programme (UNEP). (2007). Annual report 2007. Nairobi, Kenya; United Nations Environmental Programme.

United Republic of Tanzania (URT). (1976). The National Capital Master Plan Dodoma, Tanzania, Project Planning Associates Limited, Toronto, Canada

United Republic of Tanzania (URT). (1998). National Beekeeping policy. Ministry of Natural Resources and Tourism. Dar-esSalaam, Tanzania: United Republic of Tanzania Government Printer.

United Republic of Tanzania (URT). (2002). National sample census of agriculture. Volume VIII-a: REGIONAL REPORT-Dodoma.

United Republic of Tanzania (URT). (2004). National Beekeeping Programme. People and Bees. A plain language guide to the United Republic of Tanzania. United Republic of Tanzania.

United Republic of Tanzania (URT). (2008). Environmental condition of Tanzania Report. Vice President's office. Department of environment [Kiswahili version]. 
East African Journal of Forestry and Agroforestry, Volume 2, Issue 1, 2020

Article DOI: https://doi.org/10.37284/eajfa.2.2.156

United Republic of Tanzania (URT). (2014). Location and Climate of Dodoma Municipality, Dodoma Capital Development Authority, Tanzania.

United Republic of Tanzania (URT). (2002). The Forest Act No. 14 of 2002. Ministry of Natural Resources and Tourism, Dar-es-salaam, Tanzania.

Zimmerman, D. A., Turner, D. A., \& Pearson, D. J. (1996). Birds of Kenya and Northern Tanzania. Halfway House. 